\title{
PERSEPSI MASYARAKAT DAN PEMANFAATAN TERHADAP HARTA BERSAMA BAGI ISTRI YANG BEKERJA TINJAUAN HUKUM KELUARGA ISLAM (Studi Jorong Padang Koto Tuo Mungka Kecamatan Mungka)
}

\author{
Farid Kristata Putra ${ }^{1}$, Elimartati ${ }^{2}$ \\ ${ }^{1}$ Institut Agama Islam Negeri (IAIN) Batusangkar \\ e-mail: paritistata14@gmail.com \\ 2 Institut Agama Islam Negeri (IAIN) Batusangkar \\ e-mail: elimartati2013@gmail.com
}

\begin{abstract}
Studi ini mengkaji tentang persepsi masyarakat dan pemanfaatan terhadap harta bersama bagi istri yang bekerja di Jorong Padang Koto Tuo Mungka Kecamatan Mungka ditinjau dari Hukum Keluarga Islam. Permasalahannya adalah banyakny a para istri di Jorong Padang Koto Tuo yang menjadi pencari nafkah utama. Dari permasalaban tersebut muncul pertanyaan Bagaimana Tinjauan Hukum Keluarga Islam terbadap persepsi masyarakat dan pemanfaatan terhadap harta bersama tersebut. Penulisan ini merupakan penulisan lapangan. Data/bahan diperoleh dari wawancara. Setelah data terkumpul diolah dengan cara deskriptif. Dan dianalisi dengan cara pengolaban data kualitatif yaitu penguraian atau penggambaran secara tertulis tanpa menggunakan angka-angka atau statistik. Penulisan ini menemukan hasil bahwa istri yang menjadi pencari nafkah utama itu memahami perihal harta bersama tidak bertentangan dengan yang tercantum di dalam Kompilasi Hukum Islam dan Undang-undang Perkawinan serta memanfaatan secara bersama apa yang didapatnya untuk kebutuban keluarga sebingga apa yang dilakukan tersebut merupakan tabarru' bagi istri. Serta harta yang diperoleh tersebut dipergunakan untuk. kebutuban keluarga terutama anak-anaknya.
\end{abstract}

Kata kunci: Persepsi Masyarakat, Pemanfaatan Harta Bersama, Istri yang Bekerja..

\section{PENDAHULUAN}

Perkawinan tidaklah semata-mata sebagai hubungan atau kontrak keperdataan biasa,

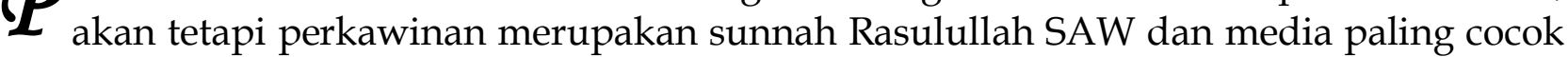
antara panduan Agama Islam dengan naluriah atau kebutuhan biologis manusia yang mengandung makna dan nilai ibadah (Rofiq, 2013, hal. 53). Salah satu diisyartakannya perkawinan adalah untuk mendapatkan ketenangan hidup, mendapatkan cinta kasih sayang serta pergaulan yang baik dalam rumah tangga. Yang demikian baru dapat berjalan secara baik bila ditunjang dengan tercukupinya kebutuhan hidup yang pokok bagi kehidupan rumah tangga. Kewajiban nafkah adalah untuk menegakkan tujuan dari perkawinan itu (Syarifuddin, 2009, hal 167).

Mencapai tujuan perkawinan dengan terpenuhinya kebutuhan yang bersifat materil itu dan ditunjang pula dengan pemenuhan kebutuhan nonmateril, maka apa yang diharapkan dengan izin Allah dan dengan itu pula tuntuan Allah untuk mendekatkan diri kepada-Nya dapat terpenuhi (Syarifuddin, 2009, 168).

Seiring berjalannya waktu dan perkembangan teknologi serta informasi telah banyak merubah tatanan dalam bermasyarakat. Hal itu juga mempengaruhi kehidupan berumah 
tangga setiap individu, sebagaimana bisa di lihat pada hari ini (Elimartati, 2008) Suami merupakan kepala rumah tangga yang berkewajiban menafkahi serta memberikan pangan, sandang dan papan kepada istrinya sebagaimana yang telah Allah SWT firmankan di dalam Qs. Al-Baqarah ayat 233:

$$
\text { ............ }
$$

\section{...Dan kewajiban ayah memberi makan dan pakaian kepada para ibu dengan cara ma'ruf....}

Pada ayat di atas Allah SWT telah mewajibkan kapala laki-laki (suami) untuk mencukupi kebutuhan istri dan juga sekaligus keluarganya. Seiring perkembangan zaman, desakan kebutuhan ekonomi rumah tangga semakin meningkat sehingga setiap kepala keluarga (suami) harus lebih giat dalam mencari nafkah. Bagi kepala keluarga yang tidak memiliki pekerjaan tetap harus lebih aktif untuk mencari lowongan pekerjaan agar tetap bisa memenuhi kebutuhan rumah tangga. Begitu juga dengan kepala keluarga yang memiliki pekerjaan tetap, tetapi penghasilan yang diperoleh belum mencukupi kebutuhan rumah tangga harus pandai mencari atau membuka lowongan pekerjaan sampingan. Tingkat pendidikan yang rendah dan semakin sempitnya lapangan pekerjaan merupakan faktor yang sering menyebabkan seorang suami tidak memiliki pekerjaan dengan penghasilan yang cukup untuk memenuhi kebutuhan rumah tangga sehingga perlu mendapat bantuan dari istri dalam mencari nafkah (Vieska Ningtyastuti,2013, hal 2)

Kondisi keluarga saat ini, banyak perempuan menanggung beban dalam membantu suami memenuhi kebutuhan rumah tangga. Perempuan yang bekerja diluar rumah juga memiliki beban kerja domestic yaitu mengurus rumah tangga. Budaya minang suami sebagai pencari nafkah tidak pantas diposisian melakukan pekerjaanpekerjaan rumah seperti mencuci, membersihkan rumah, memasak, mengasuh anak dan pekerjaan lain yang menyita waktu. Beban itu akan bertambah berat jika istri juga bekerja menggantikan posisi suaminya sebagai pencari nafkah dan juga mengerjakan pekerjaan domestiknya dalam mengurus rumah tangga (Hamidah, 2011, hal. 141)

Kenyataannya dalam kehidupan masyarakat modern saat ini banyak istri menggantikan posisi suami sebagai pencari nafkah sedangkan suami dirumah menjaga anak. Sehingga dari sektor kebutuhan rumah tangga, sandang papan dipenuhi oleh jerih payah istri. Sedangkan suami tidak begitu ambil andil dalam pemenuhan kebutuhan rumah tangga. Walaupun ambil andil dalam pemenuhan kebutuhan keluarga akan tetapi hal itu hanya sedikit saja dalam pemenuhan kebutuhan tersebut. Hal tersebut sangat banyak dilihat pada kehidupan masyarakat dewasa ini. Seperti yang dijumpai di Jorong Padang Koto Tuo Kecamatan Mungka dari 323 KK yang tercatat di Profil Jorong, hampir seluruh KK istri terlibat aktif dalam membantu pemenuhan kebutuhan keluarga (Wawancara Kepala Jorong Padang Koto Tuo, 6 November 2019)

Adapun data yang penulis ambil dari profil tersebut adalah sebagai berikut: 


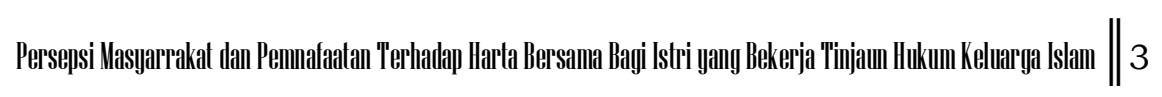

Tabel 1.0

Data Rumah Tangga yang Istri Bekerja

\begin{tabular}{|c|c|c|c|c|c|}
\hline \multirow[t]{2}{*}{ NO } & \multicolumn{2}{|c|}{ NAMA } & \multicolumn{2}{|c|}{ PEKERJAAN } & \multirow[t]{2}{*}{ TANGGUNGAN } \\
\hline & Suami & Istri & Suami & Istri & \\
\hline 1 & $\begin{array}{l}\text { Hasmi } \\
\text { Warfi }\end{array}$ & Titen Efni & - & PNS & 2 orang anak \\
\hline 2 & Edi & Nini & - & PNS & 3 orang anak \\
\hline 3 & Jasmihir & Almidarti & - & PNS & 3 orang anak \\
\hline 4 & Masradefa & Erlina Yusefa & - & PNS & 1 orang anak \\
\hline 5 & Popi & Erna Yusna & - & PNS & $\begin{array}{l}\text { Orang tua dan } 3 \\
\text { orang anak }\end{array}$ \\
\hline 6 & $\begin{array}{l}\text { Roki } \\
\text { Depito }\end{array}$ & Yusna Dewi & - & PNS & 2 orang anak \\
\hline 7 & $\begin{array}{l}\text { Denil } \\
\text { A.Rahman }\end{array}$ & Nina & - & PNS & 1 orang anak \\
\hline 8 & $\begin{array}{l}\text { Rika } \\
\text { Saputra }\end{array}$ & $\begin{array}{l}\text { Lidya Eka } \\
\text { Putri }\end{array}$ & - & PNS & 3 orang anak \\
\hline 9 & $\begin{array}{l}\text { Syamsuriz } \\
\text { al }\end{array}$ & $\begin{array}{l}\text { Mega } \\
\text { Mustika }\end{array}$ & - & PNS & 1 orang anak \\
\hline 10 & Edison & Mardiana & - & PNS & 2 orang anak \\
\hline
\end{tabular}

(Sumber Profil Jorong Padang Koto Tuo tahun 2019)

Berdasarkan data tersebut di atas, dapat dipahami bahwa istri berperan penting dalam keluarga yaitu sebagai pencari nafkah utama untuk menggantikan suami yang kurang produktif dalam memenuhi kewajibannya sebagai kepala keluarga. Begitupun juga terhadap tanggungan dalam keluarga tersebut menjadi titik tumpu istri dalam pemenuhan kebutuhannya. Terkait dengan tanggungan di dalam rumah tangga tersebut mereka rata-rata menanggung tidak kurang dari 2 orang tanggungan, artinya istri selain sebagai pencari nafkah juga memiliki beban ganda yang tertumpu kepada dirinya sendiri. Pekerjaan sehari-hari sebagai ibu rumah tangga harus dilakukan, disamping itu para istri juga menjadi penopang kebutuhan sehar-hari rumah tangga tersebut (Profil Jorong Tahun 2019)

Melihat awal sejarah di berlakukan konsep harta bersama, dapat dipahami bahwa ide untuk memunculkan pelembagaan harta bersama adalah merupakan wujud perlindungan sekaligus pengakuan terhadap hak-hak istri dalam rumah tangganya. Pada keadaan tertentu terjadi masalah dalam rumah tangga seseorang, istri tidak perlu cemas memikirkan kepentingannya secara materil sebagai bekal memenuhi kebutuhaan dasarnya seperti terjadi perceraian. Pemicu ditetapkan harta bersama dalam perkawinan antara lain kondisi masyarakat pada awalnya yang berfungsi bekerja mencari nafkah adalah suami, maka pemilik mutlak harta yang diperoleh adalah suami. Sedangkan istri tidak mempunyai saham atas terkumpulnya harta dalam perkawinan. Istri bekerja dalam rumah yang tidak menghasilkan uang, tetapi membantu suami untuk menyiapkan dan 
mengatur keperluan kehidupan dalam rumah tangga. Saat terjadi pisah rumah atau putusnya perkawinan, istri bisa saja tidak punya sesuatu apapun sebagai bekal untuk hidup. Sebagai posisi jaga-jaga mengantisipasi kelalaian suami masalah nafkah dan kurang perhatian suami secara materil terhadap istri dan anak-anaknya, maka ditetapkanlah adanya harta bersama (Elimartati, 2018, hal 4)

Seiring perkembangan zaman hal ini sudah merubah tatanan dalam masyarakat yang mana si istri sudah mampu mengahsilkan materil berupa uang sebagaimana yang terlihat di Jorong Padang Koto Tuo dimana notabene istri membantu suami dalam pemenuhan kebutuhan keluarga dan tidak jarang mneggantikan suami sebagai kepala keluarga. Hal itu tentu saja membuat konsep diberlakukannya harta bersama tadi kurang efektif dalam pelaksanaan ditengah masyarakat.

Ketidak efektifan itu terlihat dari banyaknya kaum hawa (istri) yang menggantikan peran suami sebagai pencari nafkah serta mampu menjamin kelangsungan hidupa keluarga. Disamping hal itu tentu apa yang dihasilkan oleh si istri merupakan haknya walaupun tidak ada larangan seandainya istri mau memberi apa yang ia peroleh tersebut dibagi untuk suami. Sebagaimana yang termuat dalam pasal 86 ayat 2 Kompilasi Hukum Islam bahwa "Harta istri tetap menjadi hak istri dan dikuasai penuh olehnya...". Akan tetapi harta istri yang menjadi hak serta dikuasai penuh oleh si istri tersebut sudah bercampur kedalam harta bersama diakibatkan tidak ada perjanjian perkawinan yang mengatur perihal harta bawaan maupun harta setelah terjadi pernikahan. Pemanfaatan harta bersama tersebut dipergunakan secara bersama oleh anggota keluarga baik itu untuk pemenuhan kebutuhan keluarga ataupun keperluan pribadi. Hal itu tentu saja akan mempengaruhi harta bersama keluarga tersebut dikarenakan harta pencaharian istri tidak terdapat bagian suami didalamnya serta peralatan rumah tangga yang dibelanjakan melalui penghasilan istri merupakan hak bagi si istri tersebut dalam penggunaan serta kepemilikannya (Kompilasi Hukum Islam pasal 86)

Fenomena tersebut terdapat ditengah masyarakatJorong Padang Koto Tuodimana setelahterjadi perkawinan, harta yang suami atauistri yang di miliki sebelum perkawinan dianggapmenjadihartabersama. Sehingga harta bersama tersebut tidak dilakukan pemisahan antara harta bawaan dengan harta pencarian selama perkawinan, termasuk pemisahan harta yang didapatkan oleh istri sebagai pencari nafkah utama, sehingga suami memanfaatkan secara penuh harta pencarian istri tersebut (hasil wawancara Esi Kader Jorong 24 Agustus 2019)

Berdasarkan uraian beserta fenomena tersebut penulis tertarik untuk melakukan penelitian lebih lanjut dengan judul "Persepsi Masyarakat dan Pemanfaatan Harta Bersama bagi Istri Yang Bekerja Tinjauan Hukum Keluarga Islam (Studi Di Jorong Padang Koto Tuo Mungka Kecamatan Mungka)".

\section{METODE PENELITIAN}

Penulian ini adalah penulisan lapangan. Data dikumpulkan melalui lapangan. Setelah data terkumpul diola dengan cara kualitatif yaitu penguraian atau penggambaran secara tertulis tanpa menggunakan angka-angka atau statistik. Kemudian dianalisis secara deskriptif dan dinarasikan secara efektif sehingga dapat menjawab permasalahan yang diteliti. 


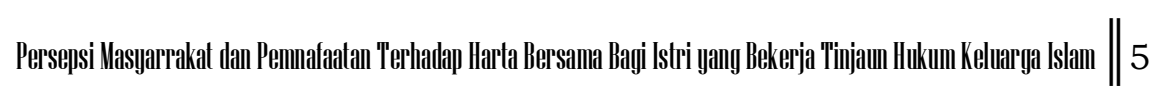

\section{HASIL DAN PEMBAHASAN}

\section{Tinjauan Hukum Keluarga Islam terhadap Harta Bersama Istri yang Bekerja}

Perspektif merupakan pandangan akan suatu hal atau suatu objek yang diterima melalui panca indera (Walgito, 2008, hal 87) Perspektif disini ialah pandangan masyarakat akan suatu hal yaitu harta bersama bagi istri yang bekerja membantu suami dalam pemenuhan kebutuhan keluarga atau sebagai pencari nafkah utama dalam suatu keluarga. Pandangan tersebut dikategorkan dalam 3 hal yaitu pengetahuan, pemahaman serta pelaksanaan yang terjadi ditengah masyarakat akan hal itu.

Perihal pengetahuan masyarakat akan harta bersama terbilang berbeda dengan atauran yang berlaku, hal itu terlihat dari pernyataan seluruh responden yang penulis wawancarai. Pengetahuan masyarakat tersebutdijawab dengan apa adanya sesuai dengan hal yang pernah dilihat dan dialaminya masing-masing individu dikehidupan bermasyarakat maupun berumah tangga sehingga hal tersebut dijawab dengan keraguan karena tidak dilandasi dengan aturan hukum maupun acuan lainnya (wawancara responden Rabu 1 Januari 2019).

Aturan terkait harta bersama sudah termuat dalam Undang-undang Perkawinan No 1 Tahun 1974 dan Kompilasi Hukum Islam. Dalam pasal 35 Undang-undang perkawinan "Harta benda selama perkawinan menjadi harta bersama" dan pasal 1 hururf f "Harta kekayaan dalamperkawinan atau Syirkah adalah harta yang diperoleh baik sendiri-sendiri atau bersama suami-isteri selama dalam ikatan perkawinan berlangsung selanjutnya disebut harta bersama, tanpa mempersoalkan terdaftar atas nama siapapun", dengan sendirinya terjadi suatu percampuran antara kekayaan suami dan kekayaan istri. Hal ini merupakan ketentuan umum apabila tidak diadakan perjanjian apa-apa. Keadaan demikian berlangsung seterusnya dan tidak dapat diubah lagi selama perkawinan berlangsung. Jika seseorang ingin menyimpang dari ketentuan tersebut maka ia harus melakukan perjanjian perkawinan. Terkait dengan hal tersebut dimuat dalam Pasal 29 Undang-undang Nomor 1 Tahun 1974 tentang Perkawinan yang menyatakan bahwa :

1) Pada waktu atau sebelum perkawinan dilangsungkan kedua belah pihak atas persetujuan bersama dapat mengajukan perjanjian tertulis yang disahkan oleh pegawai pencatat perkawinan, setelah mana isinya berlaku juga terhadap pihak ketiga tersangkut.

2) Perkawinan tersebut tidak dapat disahkan bilamana melanggar batas-batas hukum, agama dan kesusilaan.

3) Perjanjian tersebut dimulai berlaku sejak perkawinan dilangsungkan.

4) Selama perkawinan dilangsungkan perjanjian tersebut tidak dapat diubah, kecuali kedua belah pihak atas persetujuan untuk mengubah dan perubahan tidak merugikan pihak ketiga.

Sedangkan di dalam Kompilasi Hukum Islam terkait dengan perjanjian perkawinan ini termuat dalam Pasal 45 yang menyatakan bahwa : 
“Kedua calon mempelai dapat mengadakan perjanjian perkawinan dalam bentuk :

1. Taklik talak dan

2. Perjanjian lain yang tidak bertentangan dengan Hukum Islam."

Hal tersebut tidak berbeda dengan yang dilakukan oleh responden yang penulis wawancarai, dimana ketika sudah terjadi perkawinan apa yang dimiliki oleh suami-istri langsung tergabung dalam harta bersama tanpa ada namanya pemisahan. Terkait dengan perjanjian perkawinan secara keseluruhan responden yang penulis wawancarai secara langsung pada Rabu 1 Januari 2020 menjelaskan bahwasanya apa yang mereka miliki sudah melebur ke dalam harta perkawinan karena mereka tidak ambil pusing terhadap harta yang dimiliki. Karena apa yang mereka miliki dijadikan untuk pemenuhan kebutuhan dalam rumah tangga secara keseluruhan.

Terkait dengan persepsi masyarakat yang menyatakan bahwasanya apabila telah terjadi perkawinan maka harta yang mereka miliki digabungkan dan diperuntukkan untuk kepentingan rumah tangga yang mereka arungi, dalam hal tersebut sudah mencakup keperluaan seluruh anggota keluarga termasuk untuk kebutuhan anak-anak. Hal apa yangdilakukan masyarakat tidak berbeda dengan aturan perundang-undangan yang berlaku.

Karena bergabungnya harta yang dimiliki oleh masing-masing individu kedalam harta bersama diakibatkan ketidaktahuan masyarakat terhadap aturan yang berlaku sehingga harta bawaan yang seharusnya bisa dikuasai masng-masing pihak sebagaimana diatur dalam Pasal 35 ayat 2 Undang-undang perkawinan yang menyatakan bahwa :

"Harta bawaan dari masing-masing suami dan istri dan harta benda yang diperoleh masing-masing sebagai hadiah atau warisan adalah dibawah penguasaan masing-masing sepanjang para pihak tidak menentuka lain"

Hal yang sama juga termuat dalam Pasal 87 ayat 1 Kompilasi Hukum Islam yang menyatakan bahwa :

"Harta bawaan masing-masing suami dan istri dan harta yang diperoleh masing-masing sebagai hadiah atau warisan adalah dibawah peguasaan masing-masing, sepanjang para pihak tidak menentukan lain dalam perjanjian perkawinan"

Akan tetapi karena peruntukan atau pemanfaatan harta bersama itu diperuntukkan oleh seluruh anggota keluarga sehingga penguasaan serta pemanfaatan dilakuan secara bersama-sama oleh suami-istri guna keberlangsungan rumah tangga tersebut tanpa melirik perihal asal harta tersebut.

Dalam Bab XII Kompilasi Hukum Islam pasal 77 sampai dengan pasal 82 menerangkan terkait dengan Hak dan Kewajiban Suami Istri. Kewajiban suami lebih rinci dibahas dalam pasal 80 yaitu sebagai pembimbing terhadap istri dan rumah tangganya, melindungi istri dan memberikan segala sesuatu keperluan hidup berumah tangga sesuai dengan kemampuannya, memberikan pendidikan agama kepada istrinya dan memberikan kesempatan belajar pengetahuan yang berguna dan bermanfaat bagi agama, nusa dan bangsa, nafkah, biaya pendidikan anak. Sedangkan kewajiban istri dituangkan dalam pasal 83 yaitu berbakti lahir dan batin kepada suami di dalam yang dibenarkan oleh hukum Islam, dan menyelenggarakan dan mengatur keperluan rumah tangga sehari-hari 
dengan sebaik-baiknya. Sedangkan dalam Undang-undang Perkawinan No 1 Tahun 1974 hak dan kewajiban suami istri termuat dalam pasal 30 sampai dengan pasal 34.

Dalam aturan tersebut dinyatakan bahwa kewajiban suami tidak hanya sebatas sebagai kepala keluarga serta memenuhi nafkah tersebut akan tetapi suami juga memiliki kewajiban menyediakan tempat tinggal, menyediakan kebutuhan istri, memberikan ilmu agama kepada istri serta memenuhi keperluan anak-anaknya.

Begitupun juga dengan kewajiban istri yang tidak hanya sebatas sebagai ibu rumah tangga atau mengurus rumah tangga akan tetapi yang lebih utama adalah berbakti kepada suami. Ketidaktahuan akan aturan yang berlaku sehingga masyarakat masih terpaku kepada hal yang bersifat lumrah yang terjadi ditengah masyarakat membuat peraturan perundang-undangan yang berlaku tidak diterapkan dengan baik ditengah kehidupan masyarakat.

Pembagian harta bersama jika terjadi perceraian merupakan suatu hal yang harus diketahui oleh masyarakat, akan tetapi responden yang penulis wawancarai lebih menyerahkan kepada pihak yang mengetahui dan berwenang akan hal itu seperti pengadilan. Hal tersebut memang akan terjadi jika perceraian terjadi maka perkara tersebut akan diputuskan oleh pengadilan.

Namun bagian dari masing-masing individu sudah termuat dalam Kompilasi Hukum Islam pasal 97 "Janda atau duda cerai masing-masing berhak atas seperdua dari harta bersama sepanjang tidak ditentukan lain dalam perjanjian perkawinan". Kendatipun sudah jelas bagian tersebut akan tetapi dalam aturan tersebut belum dijelaskan secara rinci seperdua tersebut apakah diraih secara bersama harta tersebut atau lebih besar kontribusi suami atau istri, hal itu perlu dipahami dan dipelajari oleh masing-masing individu agar haknya selama perkawinan tidak berpindah tangan kepada pihak lain yang tidak seharusnya mendapatkan hal tersebut.Perkembangan zaman telah merubah pelaksanaan aturan yang termuat dalam pasal 97 Kompilasi Hukum Islam tersebut. Pelaksanaan dari aturan tersebut sudah melihat kepada besaran kontribusi antara suami dan istri.

Perihal pengetahuan masyarakat terkait harta bersama tersebut terkhusus kepada istri yang bekerja membantu suami dalam pemenuhan kebutuhan keluarga atau sebagai pencari nafkah utama berbeda dengan apa aturan yang berlaku. Pengetahuan masyarakat tersebut berbeda namun tidak bertentangan dengan perundang-undangan yang berlaku, tetapi karena tidak pernah menemima, membaca, memahami serta mendapatkan suatu pendidikan hukum terkait hal tersebut. Sehingga pengetahuan masyarakat tersebut hanya terfokus kepada apa yang dilihat dan dialami dalam kehidupan bermasyarakat serta berumah tangga.

Pemahaman masyarakat seperti hak istri yang tidak terpenuhi oleh suami seperti nafkah dan lainnya, tanggungan suami yang dibebankan kepada istri seperti hutang dan sebagainnya serta aset istri yang dipergunaka oleh suami beralih atas nama suami. Dalam aturan yang berlaku seperti yang termuat dalam Kompilasi Hukum Islam Pasal 80 bagian ketiga kewajiban suami ayat 4 yang menyatakan :

"Sesuai dengan penghasilannya suami menanggung : 
a. Nafkah, kiswah dan tempat kediaman bagi istri;

b. Biaya rumah tangga, biaya perawatan dan biaya pengobatan bagi istri dan anak;

c. Biaya pendidikan bagi anak."

Kendatipun demikian dalam kehidupan rumah tangga responden yang penulis wawancarai hal tersebut berbanding terbalik dimana nafkah yang seharusnya diberikan oleh suami kepada istri dikarenakan beberapa faktor membuat istri mengambil alih peran tersebut. Begitu juga terkait dengan biaya pendidikan anak maupun hal lainnya. Hal ini tentu saja berbeda dengan yang tertuang dalam aturan yang berlaku namun istri tetap rela melakukan hal tersebut dikarenakan dalam agama tidak ada larangan istri untuk membantu suami dalam pemenuhan kebutuhannya. Istri memberikan nafkah bukan dikarenakan kewajibannya tetapi lebih kepada berbuat baik kepada suaminya. Hal itupun terjadi dikarenakan suami dalam melakukan kewajibannya hanya dibebankan kepada batas kemampuannya sebagaimana yang tertuang dalam pasal 80 ayat 2 :

"Suami wajib melindungi istrinya dan memberikan segala sesuatu keperluan hidup berumah tangga sesuai dengan kemampuannya"

Kendatipun demikian jika suami tidak menunaikan kewajibannya menurut Syafi'iyah dan Hanabilah istri berhak meminta cerai, Dasar pendapat ini adalah hadits dari Said Ibnu al-Musayyab dan Abu Hurairah, bahwa Nabi SAW pernah bersabda ketika salah seorang suami yang tidak mampu memberikan nafkah kepada istrinya "pisahkan keduanya". Haditsnya sebagai berikut :

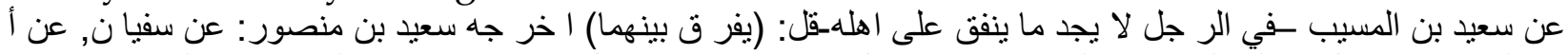

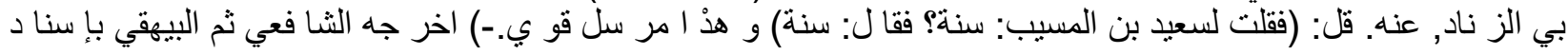

"Dari Said Ibnu al-Musayyab tentang orang yang tidak mampu memberi nafkah istrinya, ia berkata: Mereka diceraikan. Riwayat Said Ibnu Manshur dari Sufyan dari Abu al-Zanad, ia berkata: Aku bertanya kepada Said Ibnu al-Musayyab, apakah itu sunnah? Dia berkata: Ya, sunnah. Hadits ini mursal yang kuat.(Diriwayatkan oleh Syafi'i kemudian Baihaqi dengan sanad hasan)

Sedangkan perihal tanggungan suami seperti hutang yang dibebankan kepada istri yang terlaksana ditengah masyarakat dibayar oleh si istri dikarenakan suami tidak mampu membayar dikarenakan harta yang ia miliki untuk membayar tersebut tidak ada karena ia tidak bekerja. Hak tersebut tidak bertentangan dengan aturan hukum yang berlaku dalam Kompilasi Hukum Islam pasal 93 yang memuat perihal :

1. Pertanggung jawaban terhadap hutang suami atau istri dibebankan pada hartanya masing-masing.

2. Pertanggung jawaban terhadap hutang yang dilakukan untuk kepentingan keluarga dibebankan kepada harta bersama.

3. Bila harta bersama tidak mencukupi, dibebankan kepada harta suami.

4. Bila harta suami tidak ada atau mencukupi dibebankan kepada istri.

Berdasarkanaturan di atas dapat dipahami bahwa apabila hutang tersebut diperuntukkan untuk kepentingan keluarga dibebankan kepada harta bersama dan jika harta bersama tidak mencukupi maka dibebankan kepada harta suami, dan hal itu pun tidak mencukupi maka dibayarkan atau dibebankan kepada istri. Hal itu berlaku untuk 


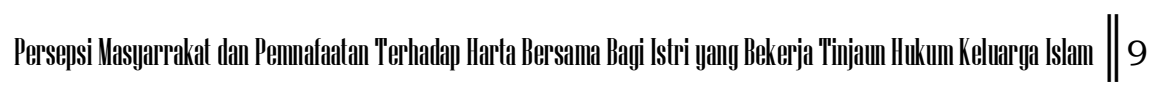

hutang yang dibuat untuk kepentingan keluarga dan hal itu tidak berlaku seandainya hutang tesebut diperbuat demi kepentingan masing-masing individu.

Apabila hal itu terjadi maka untuk pembayarannya dibebankan kepada masingmasing individu yang berhutang tersebut tanpa membebankan kepada pihak yang tidak melakukan perbuatan itu. Walaupun ditengah masyarakat ketidak etisan itu terjadi seperti demikian dimana istri yang membayarkan hutang yang dibuat oleh suami. Akan tetapi demi keharmonisan dalam keluarga istri tetap pada koridornya mempertahanan rumah tangganya (hasil wawancara Rabu 1 Januari 2019)

Aset yang dipergunakan oleh suami yang berasal dari istri harus dilihat hal itu apakah demi kepentingan keluarga atau tidak serta harta tersebut berasal dari harta bersama atau harta bawaan, jika hal itu berasal dari harta bawaan maka dalam aturan yang berlaku hal itu tidak diperkenankan karena terhadap harta tersebut masing-masing pihak memiliki hak penuh sebagaimana termuat dalam pasal pasal 87 ayat 2 Kompilasi Hukum Islam "Suami dan isteri mempunyai hak sepenuhnya untuk melakukan perbuatan hukum atas harta masing-masing berupa hibah, hadiah, sodaqah atau lainnya".

Melanjutkan kepada pelaksanaan harta bersama dalam keluarga atau rumah tangga responden dimana hal yang terjadi masih didasarkan pada pemahaman serta pengetahuan yang bersumber dari keluarga maupun yang terjadi ditengah masyarakat dalam kehidupan rumah tangga responden.Hal tersebut seperti perihalnya pelaksanaan harta bersama yang terjadi dalam keluarga responden, pengelolaan harta bersama tersebut, kemudian kelebihan dari harta bersama tersebut serta persoalan yang muncul terkait harta bersama.

Pelaksanaan harta bersama dalam keluarga responden berbeda dengan aturan hukum yang berlaku dimana setelah terjadi perkawinan seluruh harta melebur kedalam harta bersama tanpa ada mengenal apakah harta tersebut didapat sebagai hadiah, wasiat, atau warisan. Sedangkan dalam aturan yang berlaku dalam pasal 35 ayat 2 Undangundang perkawinan "Harta bawaan dari masing-masing suami dan isteri dan harta benda yang diperoleh masing-masing sebagai hadiah atau bawaan adalah di bawah penguasaan masing-masing sepanjang tidak menentukan lain"hal tersebut juga senada dengan yang termuat dalam pasal 87 ayat 1 "Harta bawaan masing-masing suami dan isteri dan harta yang diperoleh masing-masing sebagai hadiah atau warisan adalah dibawah penguasaan masing-masing sepanjang para pihak tidak menentukan lain dalam perjanjian perkawinan"

Dikarenakan masyarakat tidak memahami akan adanya harta bawaan yang terpisah dari harta perkawinan atau harta bersama. Begitupun juga terkait dengan adanya perjanjian perkawinan perihal harta bawaan tersebut yang sudah termuat sebelumnya dalam aturan yang berlaku yaitu dalam pasal 29 Undang-undang perkawinan :

1) Pada waktu atau sebelum perkawinan dilangsungkan kedua belah pihak atas persetujuan bersama dapat mengajukan perjanjian tertulis yang disahkan oleh pegawai pencatatan perkawinan, setelah mana isinya berlaku juga terhadap pihak ketiga tersangkut. 
2) Perkawinan tersebut tidak dapat disahkan bilamana melanggar batas-batas hukum, agama dan kesusilaan.

3) Perjanjian tersebut dimulai berlaku sejak perkawinan dilangsungkan.

4) Selama perkawinan dilangsungkan perjanjian tersebut tidak dapat diubah, kecuali bila dari kedua belah pihak ada persetujuan untuk mengubah dan perubahan tidak merugikan pihak ketiga.

Berdasarkan hal di atas dapat dipahami bahwa sebelum perkawinan berlangsung bisa diadakan perjanjian perkawinan terhadp hal-hal yang dirasa perlu oleh masingmasing pihak. Akan tetapi masyarakat masih terpaku kepada apa yang dilihat dan dialami dalam kehidupan bermasyarakat serta dalam berumah tangga, sehingga apa yang berlaku menjadi terkesampingkan karena perihal ketidaktahuan akan hal tersebut.

Perihal pengelolaan harta bersama, suami dan istri memiliki tanggung jawab menjaga harta bersama termasuk dalam pengelolaan harta tersebut, hal itu termuat dalam pasal 89 Kompilasi Hukum Islam "Suami bertanggung jawab menjaga harta bersama, harta isteri maupun harta sendiri" dan pasal 90 Kompilasi Hukum Islam "Isteri turut bertanggung jawab menjaga harta bersama maupun harta suami yang ada padanya" . Dalam aturan tersebut dinyatakan bahwa suami dan istri bertanggung jawab dalam mengelola harta bersama yang dimilinya. Hal demikian juga disampaikan oleh masingmasing responden yang penulis wawancarai, sehingga aturan hukum yang berlaku tidak berbeda dengan pelaksanaan ditengah masyarakat walaupun masyarakat tersebut tidak memahami aturan hukum yang berlaku tersebut dan lebih merujuk kepada kebiasaan yang sudah terjadi turun temurun ditengah masyarakat.

Dalam mengarungi bahtera rumah tangga tidak sedikit dari suatu keluarga tersebut mengakhiri hubungannya dengan perceraian dikarenakan oleh berbagai faktor sehingga peran peradilan sangat dibutuhkan terutama untuk menyelesaikan sengketa yang muncul setelah terjadinya percerian yaitu harta bersama. Perihal harta bersama jika terjadi perceraian diatur dalam pasal 37 BAB VIII tentang harta benda dalam perkawinan yang menyatakan :

"Bila perkawinan putus karena perceraian, harta benda diatur menurut hukum masingmasing"

Sedangkan dalam Kompilasi Hukum Islam diatur bahwasanya jika terjadi perceraian maka harta bersama tersebut dibagai seperdua bagian untuk suami dan seperdua bagian untuk istri sesuai yang termuat dalam Pasal 97. Di tengah masyarakat Jorong Padang Koto Tuo yang penulis wawancarai sebagai responden menyatakan bahwasanya walaupun terdapat kekurangan serta tidak terlaksananya suatu kewajiban oleh salah satu pihak tidak membuat rumah tangga tersebut berakhir sehingga mereka tetap mempertahankan dengan menyelesaikan polemik tersebut dalam ranah kekeluargaan.

Walaupun perceraian tidak terajadi namun responden yang penulis wawancarai tersebut tidak memahami terkait bagian dari hak masing-masing individu jika suatu saat perkawinan mereka berakhir dan harta yang mereka miliki akan dibagi sesuai dengan atauran yang berlaku. Masyarakat lebih terpaku kepada pihak atau lembaga yang 


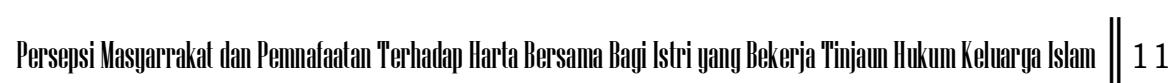

berwenang dalam hal ini untuk menyelesaikan sengketa yang ada termasuk didalamnya pembagain harta bersama.

Persepsi masyarakat terhadap harta bersama istri yang bekerja jika ditinjau dari tinjauan hukum keluarga islam tidak ada yang bertentangan dengan aturan yang berlaku namun apa yang dinyatakan oleh masing-masing responden berbeda. Hal itu diakibatkan oleh masyarakat yang tidak memahami, mengetahui, serta mendapatkan pendidikan ataupun pelatihan klinis hukum terkait dengan hal tersebut, sehingga persepsi masyarakat tersebut masih mengacu kepada konsep yang sudah biasa atau lumrah terjadi ditengah masyarakat atau yang dialami langsung oleh individu-individu responden yang penulis wawancarai.

Masyarakat masih menerapkan adat atau kebiasaan yang terjadi sebagai suatu hukum yang harus berlaku ditengah-tengah masyarakat dan sehingga aturan hukum seperti perundang-undangan tersebut berlaku jika masyarakat keluar dari ranah kebiasaan tersebut. Sera kedudukan istri sebagai pencari nafkah dalam keluarga bukanlah suatu kewajiban baginya melainkan sebagai ibadah, hal tersebut sesuai dengan hadits Rasulullah SAW dari Zainab istri Abdullah menceritakan bahwa harta penghasilan pencaharian Zainab dan istri dari kaum Anshar dizakatkan kepada suami dan diberikan untuk memenuhi kebutuhan anak yatim yang mereka pelihara. Dari hadis ini dapat dipahami bahwa harta pencaharian istri dimanfaatkan untuk kebutuhan keluarga bukan merupakan kewajibannya, tetapi istri boleh memberikan hartanya untuk keluarga, walaupun berbentuk zakat sebagaimana yang dijelaskan hadis berikut ini:

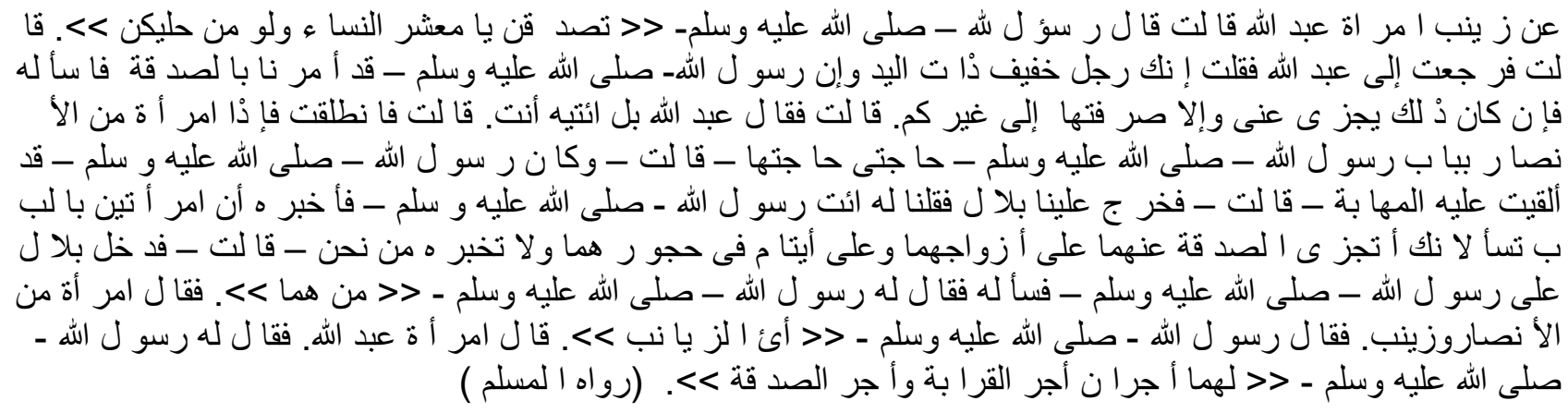

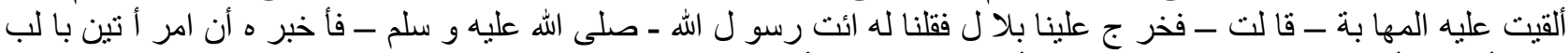

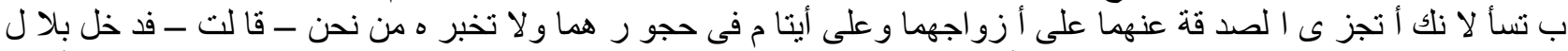

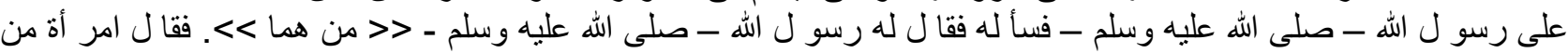

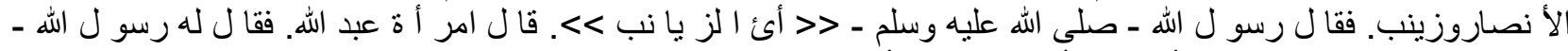

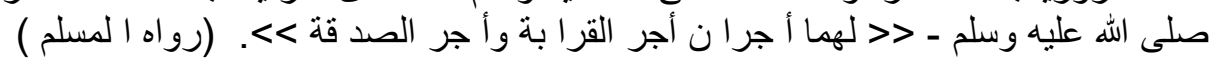

Dari Zainab istri Abdullah bin Mas'ud ia berkata bahwa Rasulullah SAW bersabda "bersedekahlah kamu sekalian wahai para perempuan, walaupun dari perhiasanmu. Zainab berkata, Aku kembali kepada Abdullah, lalu berkata kepadanya, engkau adalah seorang laki-laki ringan yang mempunyai tangan (kiasan dari keadaan fakir), dan sesungguhnya Rasulullah SAW telah menyuruh kami untuk bersedekah, datanglah kepadanya dan tanyakanlah, apabila hal itu diperolehkan kepadaku, kalau tidak akan aku berikan sedekah itu pada orang selain kamu. Dari Zainab, berkata Abdullah, pergilah kamu sendiri, Zainab berkata, kemudian aku berangkat, ternyata ada seorang perempuan dari golongan anshar di pintu rumah Rasulullah SAW yang keperluannya sama dengan keperluanku. Perempuan itu merasa berat berhadapan dengan Rasulullah SAW. kemudian keluarlah menyonsong kami Bilal, lalu kami berkata kepadanya, datanglah kamu kepada Rasulullah $S A W$, lalu ceritakanlah bahwa ada dua orang perempuan di pintu yang menanyakan kepadamu apakah sedekah keduanya dianggap sah bila diberikan kepada suaminya dan pada anak-anak yatim 
yang dipelihara keduanya. Dan jangan engkau ceritakan kepada Rasulullah SAW siapa kami.Kemudian Bilal masuk lalu menanyakan kepada Rasulullah SAW. Rasulullah SAW berkata: siapa mereka berdua itu ?Bilal menjawab Zainal istri Abdullah. Rasulullah SAW bersabda: mereka mendapat dua pahala, pahala kerabat dan pahala sedekah. (HR Bukhari dan Muslim)

Berdasarkan hadits di atas dapat dipahami bahwa pemanfaatan hasil usaha pencarian istri kebanyakan digunakan untuk amal ibadah secara umum yang merupakan tabarru' bagi istri, boleh untuk keluarganya dan juga boleh dimanfaatkan oleh orang lain secara umum. Walaupun tidak ada nash yang menganjurkan perempuan menafkahi keluarganya, namun bersedakah lebih diutamakan kepada keluarga dekat, akan mendapatkan dua pahala yaitu pahala silaturrahmi dengan keluarga dekat dan pahala sedekah.

\section{KESIMPULAN}

Berdasarkan hasil penulisan yang telah dilakukan mengenai "Persepsi Masyarakat dan Pemanfaatan Terhadap Harta Bersama Istri yang Bekerja Tinjauan Hukum Keluarga Islam di Jorong Padang Koto Mungka Kecamatan Mungka" dapat disimpulkan :

1. Persepsi masyarakat terhadap harta bersama bagi istri ditinjau dari hukum keluarga Islam berbeda dengan aturan yang berlaku namun hal itu tidak bertentangan dengan apa yang termuat dalam Undang-undang No 1 Tahun 1974 tentang Perkawinan dan Kompilasi Hukum Islam.

2. Persepsi masyarakat tersebut ditinjau dalam hukum keluarga Islam masih belum mencakup kepada aspek-aspek yang termuat di dalam aturan hukum yang berlaku. Hal tersebut diakibatkan oleh pengetahuan, pemahaman serta pelaksanaan harta bersama serta pemanfaatan harta itu masih mengaju kepada apa yang terjadi dan dialami oleh masing-masing individu selama berumah tangga.

\section{Daftar Pustaka}

Elimartati. (2018). Harta Kekayaan dalam Perkawinan. Yogyakarta: Dialektika.

Hamidah, t. (2011). figh perempuan berwawasan keadilan gender. malang: uin malik press.

Indonesia, D. A. Al-Quran dan Terjemah. Jakarta: Syamiil Quran.

Kompilasi Hukum Islam.

Ningtyastuti, V. (2013). Kesetaraan gender bagi perempuan pekerja di sector publik. 2.

Rofiq, A. (2013). Hukum Perdata Islam di Indonesia. Jakarta: Rajawali Press.

Syarifuddin, A. (2006). Hukum Perkawinan Islam di Indonesia. Jakarta: Kencana.

Undang-undang No 1 Tahun 1974 tentang perkawinan.

Walgito, B. (2002). Pengantar Psikologi Umum. Yogyakarta: Andi Offset.

Wawancara Kepala Jorong 6 November 2019. 